\title{
Recovery of Vegetative Cover and Soil Organic Mat- ter during Revegetation of Abandoned Farmland in a Semiarid Climate
}

\section{J.F. DORMAAR AND S. SMOLIAK}

\begin{abstract}
Much of the farmland in the Canadian Prairie region has been abandoned over the years and allowed to revert to weedy cover and eventually to grassland. While some of the changes in vegetation during plant succession have been documented, limited information is available on changes in soil characteristics. The purpose of this study was to assess the vegetative cover and soil transformation under similar semiarid climatic conditions with an annual precipitation of about $310 \mathrm{~mm}$ on 3 sites abandoned in 1925, 1927, and 1950 as compared to adjacent native range. Total $C$ and $N$, water-stable aggregates between 1.0 and $5.0 \mathrm{~mm}$, and polysaccharide content increased, while chelating resin-extractable $\mathbf{C}$, humic acid/fulvic acid ratios, caloric content of the rootmass, and dehydrogenase activity decreased in the successional sequence. Nevertheless, more than 55 years will be required to allow soil to return to native range standards under moderate grazing by livestock. Revegetated range may have to be subjected to lighter grazing pressures than usual to allow the vegetation to continue to increase its rootmass and thus the soil chemical properties. $A$ hypothesis to explain changes in root-and top-mass ratios with time on the basis of the quality of soil nitrogen has been advanced.
\end{abstract}

Many of the level grasslands in southeast Alberta and southwest Saskatchewan were cultivated early in this century. However, from 1916 to 1935, it became evident that many of these areas were entirely unsuited for crop production because of adverse climatic conditions and the nature of the marginal or submarginal lands that were cultivated. A combination of a series of years of average or below average rainfall, drifting soil, and low prices of agricultural products forced many settlers to abandon their farms. Some 1.6 million hectares of abandoned farmlands were allowed to revert to annual and perennial weeds and eventually to grassland. Across the border in Montana, U.S.A., the economic situation was much better after the severe drought between 1917 and 1921 (Gieseker 1931) and dryland farming was firmly established. However, large parts of southern Alberta and Saskatchewan, Canada, were considered unsuitable for cultivation and have remained in permanent rangeland (Fig. 1).

A recent study assessed the possible impact of 40 to 49 -year-old stands of crested wheatgrass on soil organic matter characteristics, by comparing four stands with adjacent native range (Dormaar et al. 1978, 1980). At one seemingly native range site, 49 years of

\footnotetext{
Authors are soil scientist and rangeland ecologist, respectively, Agriculture Canada, Research Station, Lethbridge, Alta. TIJ $4 \mathrm{BI}$

The authors thank C.D. Bricker, Administrator, Alberta Remote Sensing Centre, Alberta Environment, Edmonton, for permission to use the Landsat border scene (Fig. 1).

Manuscript accepted April 15, 1985.
}

naturally reverting to native range after 10 years of cultivation was not sufficient time for the soil to have chemical and physical characteristics similar to those of adjacent native range. This was of interest in terms of time as a soil-forming factor. Old-field successions have been described by Booth (1941), Whitman et al. (1943), Tomanek et al. (1955), and Haug and Van Dyne (1968), while Rice (1976) explained the causes of succession. The purpose of this study was to assess the vegetation and changes in a number of soil chemical properties during the succession of abandoned cropland to native range under semiarid climatic conditions.

\section{Materials and Methods}

\section{Sites}

Three fields of similar topography at the Agriculture Canada Research Substation, Manyberries, Alta., were chosen for the study. The fields included sites containing cropland, abandoned 30 to 55 years before the study and allowed to revegetate by secondary succession, and adjoining unbroken native range of the Mixed Prairie Association. The native range and the adjacent cultivated areas have been grazed by cattle at a moderate rate to provide a $50 \%$ carryover of forage.

The treatment received by the abandoned fields was as follows: Site 1925-The revegetating field was ploughed in 1910, cultivated for 15 years, and abandoned in 1925 .

Site 1927-The revegetating field was ploughed in 1917 , cultivated for 10 years, and abandoned in 1927

Site 1950 - The revegetating field was ploughed in 1920 , cultivated intermittently for 30 years, and abandoned in $\mathbf{1 9 5 0 .}$

\section{Vegetation}

Vegetative ground cover and species composition of the study sites were determined by the vertical point method (Lodge and Campbell 1965). A total of 2,100 points were located at each site in August, 1981. Nomenclature for vascular plants follows that given by Moss (1959). Forage yields were obtained by harvesting the plants at ground level in 10 randomly located $1-\mathrm{m}^{2}$ quadrats at each site in August, 1981 and 1982, and oven-drying the harvested samples.

\section{Soil}

The soils are members of the Orthic Brown Subgroup of the Chernozemic Order (Aridic Ustochrept): a dark yellowish brown (10YR 4/4, wet) friable Ah surface horizon of $7 \mathrm{~cm}$ with $\mathrm{pH} \mathrm{H}_{2} \mathrm{O}$ of 6.9 is underlain by about $13 \mathrm{~cm}$ of a brown (10YR $5 / 3$, wet) columnar $\mathrm{Bm}$ horizon with a $\mathrm{pH} \mathrm{H}_{2} \mathrm{O}$ of 6.1 ; the $\mathrm{Ck}$ horizon occurs 


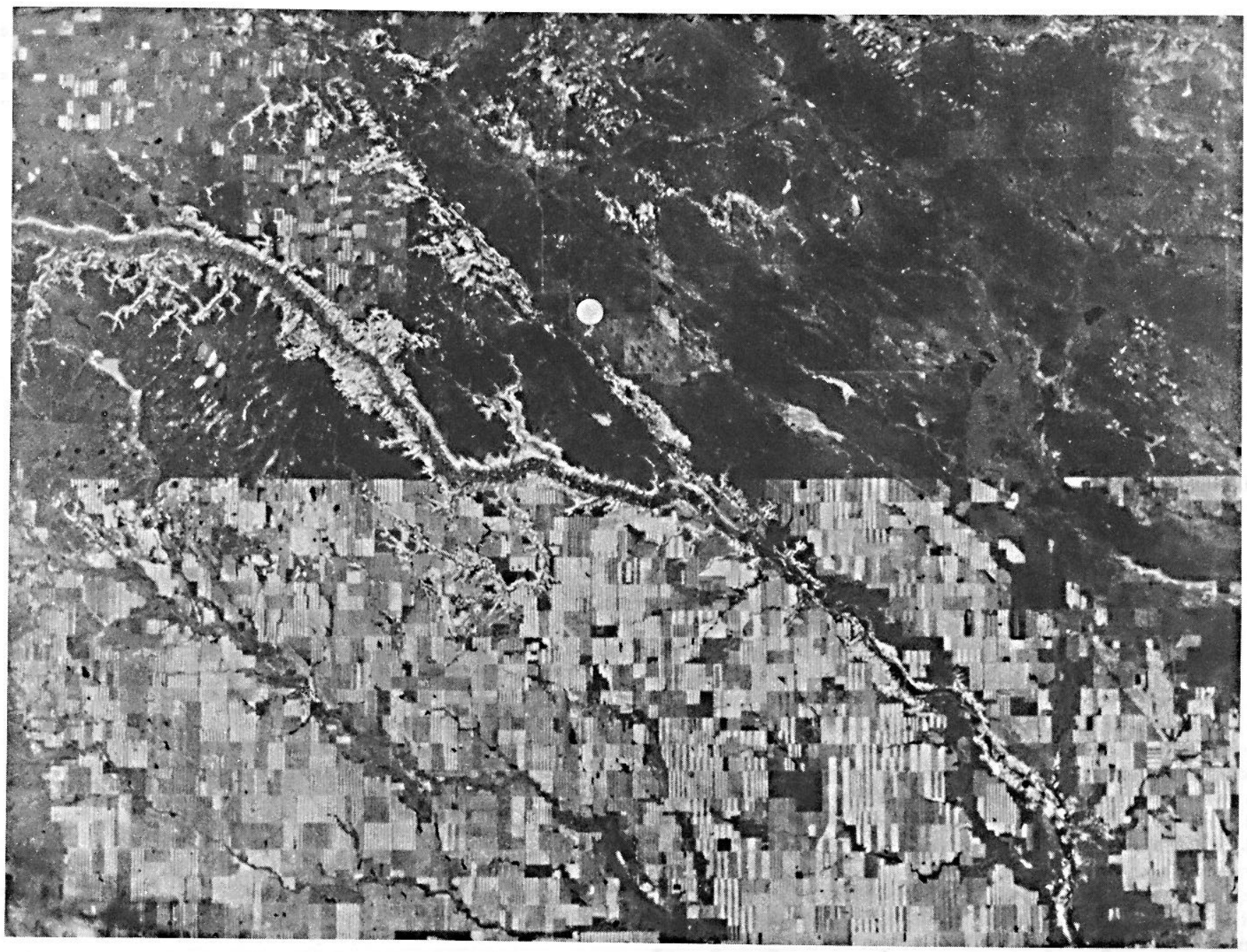

Fig. 1. A Landsat 3 scene of the Canada (Alberta)- United States (Montana) border recorded on 26 July 1978. The border is sharply defined by different land-use practices: rangeland in southeastern Alberta and strip-farming in Montana. (The white dot in the center of the picture indicates the general location of the study sites.)

at about $20 \mathrm{~cm}$ below the surface, is very pale brown (10YR $7 / 3$, wet) and has a $\mathrm{pH} \mathrm{H}_{2} \mathrm{O}$ of 7.7. The climate is semiarid and annual precipitation averages about $310 \mathrm{~mm}$.

Ten soil cores, $6.5 \times 60 \mathrm{~cm}$, were obtained at random locations (April, 1982) from each field and the roots in each 15-cm increment were washed by the method essentially as described by Lauenroth and Whitman (1971). Weight of organic mass was calculated on an ash-free, oven-dry basis (daf). Energy content of the roots from the $0-15-\mathrm{cm}$ level was determined on 0.5-g samples in a Parr adiabatic calorimeter and expressed on a daf basis.

The Ah horizon (0-15-cm) was sampled (September, 1980) on 3 subplots in each of 4 sampling areas with similar landscape position within each field. The subplot samples were combined, mixed, air-dried, and ground to pass through a 1-mm screen. Organic matter (OM) was determined by the method outlined by Walkley and Black (1934), chelating resin-extractable carbon (C) and the humic acid/fulvic acid carbon ratios as described by Dormaar (1973), total nitrogen (N) as by Association of Official Agricultural Chemists (1950), hydrolysable-N, hexosamine-N, and amino acidN (on samples collected in April, 1982) as by Bremner (1965), and polysaccharides as by Brink et al. (1960). Dehydrogenase activity was determined at pH 7.6 on fresh, moist soil (September, 1980) within 24 hours after its collection by measuring the triphenylformazan (formazan) produced by reduction of 2,3,5-triphenyltetrazolium chloride when soil was incubated with 2-amino-2-(hydroxymethyl)propane-1:3-diol buffer $(0.5 \mathrm{M})$ at $30^{\circ} \mathrm{C}$ for 5 hours
(Ross 1971). The soil variables chosen were considered to be sensitive indicators of soil changes and have been used previously (Dormaar et al. 1978).

Water-stable aggregates (April, 1982) were determined by the wet-sieving technique (Yoder 1936); undisturbed cores were analyzed for bulk density (U.S. Salinity Laboratory Staff 1954).

It is recognized that chemical, physical, and vegetational changes that may occur within and on the soil are undoubtedly affected by a host of environmental changes that vary with years. Ideally, the most accurate assessment of such changes could be made from repeated analyses of samples taken periodically from well-replicated field plot tests over many years. Although replication and application of current statistical analyses to newly established field plot experiments is common and undeniably desirable and useful, valid information and data can still be gained from early established, unreplicated field experiments, including revegetation of abandoned farmland studies, by virtue of their antiquity (Ridley and Hedlin 1968, Dormaar and Pittman 1980, Dormaar 1983). Time has exerted a type of replication on the revegetation of the abandoned farmland study described here.

Multiple sampling of a single plot at any one time reduces variance attributable to analytical sampling errors (Federer 1955), but does not constitute a replication of the applied treatment. Standard errors were calculated to check the variability within the results of any analysis for each set of 4 soil samples, but they were not tabulated. The root weights were analyzed using analysis 
Table 1. Vegetative ground cover (\%) by species and forage yield on native range and revegetated native range, Manyberries, Alberta, $1981-82$.

\begin{tabular}{|c|c|c|c|c|c|c|}
\hline \multirow[b]{3}{*}{ Species } & \multicolumn{6}{|c|}{ Year of abandonment } \\
\hline & \multicolumn{2}{|c|}{1925} & \multicolumn{2}{|c|}{1927} & \multicolumn{2}{|c|}{1950} \\
\hline & Native & Revegetated & Native & Revegetated & Native & Revegetated \\
\hline \multicolumn{7}{|l|}{ Grasses and Sedges } \\
\hline Blue grama & 3.10 & $6.76^{* *}$ & 2.24 & $4.38^{* *}$ & 3.05 & $6.52 * *$ \\
\hline Needle and thread & 3.95 & 2.95 & 3.19 & 2.38 & 4.19 & 2. 14* \\
\hline Junegrass & 1.80 & $0.38^{* *}$ & 1.76 & 1.00 & 1.52 & 1.00 \\
\hline Western wheatgrass & 0.48 & 0.14 & 0.38 & 0.29 & 0.38 & 0.14 \\
\hline Others & 0.63 & 0.57 & 0.43 & 0.72 & 0.34 & 0.05 \\
\hline Total & 9.96 & 10.80 & 8.00 & 8.77 & 9.48 & 9.85 \\
\hline \multicolumn{7}{|l|}{ Shrubs and Forbs } \\
\hline Fringed sage & 0.10 & 0.00 & 0.00 & 0.00 & 2.43 & $0.95^{* *}$ \\
\hline Other shrubs & 0.00 & 0.53 & 0.95 & 0.19 & 0.05 & 0.19 \\
\hline Forbs & 0.72 & $0.10^{*}$ & 0.10 & 0.48 & 0.34 & 0.38 \\
\hline Total & 0.82 & 0.63 & 1.05 & 0.67 & 2.82 & $1.52^{* *}$ \\
\hline Little clubmoss & 0.00 & 0.00 & 0.14 & 0.14 & 0.00 & 0.00 \\
\hline Total number of species & 13 & 10 & 12 & 11 & 13 & 10 \\
\hline \multicolumn{7}{|l|}{ Forage yield (kg/ha) } \\
\hline 1981 & 166 & 322 & 215 & 414 & 338 & 784 \\
\hline 1982 & 244 & 392 & 380 & 620 & 292 & 440 \\
\hline Mean & 205 & 357 & 298 & 517 & 315 & 612 \\
\hline
\end{tabular}

**,* Significantly different at the $1 \%$ and $5 \%$ levels, respectively, as determined by the Chi-Square test.

Table 2. Below-ground biomass $\left(\mathrm{g} / \mathrm{m}^{2}\right)$ on native range and revegetated range, Manyberries, Alberta, 1982 (average of $10 \mathrm{cores} 6.5-\mathrm{cm}$ diameter $\times 15-\mathrm{cm}$ depth).

\begin{tabular}{|c|c|c|c|c|c|c|c|c|}
\hline \multirow{3}{*}{$\begin{array}{c}\text { Increment } \\
(\mathrm{cm})\end{array}$} & \multicolumn{6}{|c|}{ Year of abandonment } & & \\
\hline & \multicolumn{2}{|c|}{1925} & \multicolumn{2}{|c|}{1927} & \multicolumn{2}{|c|}{1950} & \multicolumn{2}{|c|}{ Mean } \\
\hline & Native & Revegetated & Native & Revegetated & Native & Revegetated & Native & Revegetated \\
\hline $0-15$ & $1,373 * *$ & 808 & $1,385^{* *}$ & 716 & $1,058^{* *}$ & 618 & $1,272^{* *}$ & 714 \\
\hline $15-30$ & $406^{*}$ & 357 & $466^{*}$ & 408 & $555^{* *}$ & 361 & $476^{*}$ & 375 \\
\hline $30-45$ & $300 * *$ & 264 & $428^{* *}$ & 309 & $337^{* *}$ & 181 & $355^{* *}$ & 251 \\
\hline $45-60$ & $315^{* *}$ & 199 & $290^{* *}$ & 244 & $212 * *$ & 125 & $272^{* *}$ & 189 \\
\hline Total & $2,394 * *$ & 1.628 & $2,569 * *$ & 1,677 & $2,162 * *$ & 1,285 & $2,375 * *$ & 1,530 \\
\hline $\begin{array}{c}\text { Caloric content } \\
(\mathrm{kJ} / \mathrm{g})\end{array}$ & 19.2 & 19.2 & 19.3 & 19.5 & 19.3 & 22.4 & & \\
\hline $\begin{array}{l}\text { Potential energy } \\
\qquad\left(\mathrm{kJ} / \mathrm{m}^{2}\right)\end{array}$ & 26,362 & 15,514 & 26,731 & 13,943 & 20,419 & 13,709 & & \\
\hline
\end{tabular}

*,** Significantly different from adjacent revegetated range at $P \leq 0.05$ and $P \leq 0.01$, respectively.

of variance techniques, while the vegetative ground cover was compared by the Chi-Square Goodness-of-fit test. The soil characteristics were analyzed by paired analyses ( $t$-test) for each year. An analysis of variance test was also used to compare the year means, realizing, of course, that there is a loss of accuracy.

\section{Results}

\section{Vegetation}

Species composition of the vegetation on the native and revegetated range sites differed (Table 1) as there was much more blue grama (Bouteloua gracilis (HBK) Lag.) cover on the revegetated range than on the native range sites. There was less needle-andthread (Stipa comata Trim. and Rupr.) on the 1950 revegetated site and less junegrass (Koeleria cristata Pers.) on the 1925 revegetated site than on adjacent native range sites. The amounts of western wheatgrass (Agropyron smithii Rydb.) and the total of other grasses and sedges were similar on the revegetated range and the native range sites. The total vegetative ground cover of all grasses and sedges was similar on the revegetated and native range sites.

Total ground cover of fringed sage (Artemisia frigida Willd.) was greater on the 1950 native range site than on the revegetated site. The ground cover of forbs was greater on the 1925 native range site than on the revegetated site. Little clubmoss (Selaginella densa Rydb.) was present only on the 1927 sites. There were more species recorded on the native range sites than on the revegetated range sites.

Total forage production was greater on the revegetated range than on the native range in both years (Table 1). Mean forage yields were from 73 to $94 \%$ greater on the revegetated range sites.

Below-ground biomass was consistently greater on native range sites than on revegetated range sites (Table 2). The greatest difference, from 70 to $93 \%$, occurred in the top $15-\mathrm{cm}$ increment while the smallest difference was in the next $15-$ to $30-\mathrm{cm}$ increment. Although the rootmass in the 0 - to $15-\mathrm{cm}$ increment of the native range next to the 1950 revegetated soil was considerably lower as compared to the other 2 native range fields, the examined chemical properties of the soil of the 3 native range fields were similar.

\section{Soil}

Total OM and total $\mathrm{N}$ of the revegetated soil were higher in the 1925 abandoned site than in the 1950 abandoned site (Table 3). However, this provided only limitcd information in terms of the composition of the OM. Although the 1950 revegetated soil had the lowest OM content, more of this OM was extractable by 
Table 3. Characteristics of the organic matter of Ah horizons of native range and revegetated native range (average of four samples)

\begin{tabular}{|c|c|c|c|c|c|c|c|c|c|c|c|c|c|c|}
\hline \multirow{3}{*}{$\begin{array}{l}\text { Year } \\
\text { of } \\
\text { abandon- } \\
\text { ment }\end{array}$} & \multirow{3}{*}{$\begin{array}{l}\text { Status } \\
\text { of } \\
\text { range }\end{array}$} & \multirow{3}{*}{$\begin{array}{c}\text { Organic } \\
\text { matter } \\
(\%)\end{array}$} & \multirow{3}{*}{$\begin{array}{c}\text { Total } \\
\mathbf{N} \\
(\%) \\
\end{array}$} & \multirow{3}{*}{$\begin{array}{c}\text { Resin- } \\
\text { extract- } \\
\text { able C } \\
\text { C } \\
(\%)\end{array}$} & \multirow[b]{3}{*}{ HA/FA' } & \multicolumn{2}{|c|}{$\begin{array}{c}\text { Water-stable } \\
\text { aggregates } \\
\end{array}$} & \multirow{3}{*}{$\begin{array}{c}\text { Bulk } \\
\text { density } \\
\left(\mathrm{g} / \mathrm{cm}^{3}\right) \\
\end{array}$} & \multicolumn{4}{|c|}{ Hydrolysable N } & \multirow{3}{*}{$\begin{array}{c}\text { Poly- } \\
\text { saccha- } \\
\text { rides } \\
(\mathrm{mg} /- \\
100 \mathrm{~g})\end{array}$} & \multirow{3}{*}{$\begin{array}{l}\text { Dehyd- } \\
\text { rognase } \\
\text { activity }\end{array}$} \\
\hline & & & & & & \multirow{2}{*}{$\begin{array}{c}\text { Total } \\
(\%)\end{array}$} & \multirow{2}{*}{$\begin{array}{l}>1.0 \\
\mathrm{~mm} \\
(\%)\end{array}$} & & Total & $\begin{array}{c}\text { Amino } \\
\text { acid }\end{array}$ & $\begin{array}{l}\text { Hexos- } \\
\text { amine }\end{array}$ & $\begin{array}{c}\text { Ammo- } \\
\text { nium }\end{array}$ & & \\
\hline & & & & & & & & & & (\% of 1 & otal N) & & & \\
\hline 1925 & $\begin{array}{l}\text { Native } \\
\text { Revegetated }\end{array}$ & $\begin{array}{l}1.82^{* *} \\
1.63\end{array}$ & $\begin{array}{l}0.148^{* *} \\
0.137\end{array}$ & $\begin{array}{l}26.8 \\
28.7\end{array}$ & $\begin{array}{l}3.51 \\
3.48\end{array}$ & $\begin{array}{l}62.9 \\
62.8\end{array}$ & $\begin{array}{l}36.9 \\
36.7\end{array}$ & $\begin{array}{l}1.30 \\
1.29\end{array}$ & $\begin{array}{l}76 \\
76\end{array}$ & $\begin{array}{l}44 \\
43\end{array}$ & $\begin{array}{l}7 \\
6\end{array}$ & $\begin{array}{l}15^{* *} \\
17\end{array}$ & $\begin{array}{l}342 \\
339\end{array}$ & $\begin{array}{l}31 \\
36\end{array}$ \\
\hline 1927 & $\begin{array}{l}\text { Native } \\
\text { Revegetated }\end{array}$ & $\begin{array}{l}1.80^{* *} \\
1.54\end{array}$ & $\begin{array}{l}0.151^{* *} \\
0.135\end{array}$ & $\begin{array}{l}27.7^{*} \\
32.3\end{array}$ & $\begin{array}{l}3.54^{*} \\
2.97\end{array}$ & $\begin{array}{l}62.7 \\
64.3\end{array}$ & $\begin{array}{l}36.7 \\
36.1\end{array}$ & $\begin{array}{l}1.29 \\
1.29\end{array}$ & $\begin{array}{l}75 \\
77\end{array}$ & $\begin{array}{l}43 \\
44\end{array}$ & $\begin{array}{l}6 \\
7\end{array}$ & $\begin{array}{l}16^{*} \\
17\end{array}$ & $\begin{array}{l}347^{* *} \\
273\end{array}$ & $\begin{array}{l}32^{* * *} \\
42\end{array}$ \\
\hline 1950 & $\begin{array}{l}\text { Native } \\
\text { Revegetated }\end{array}$ & $\begin{array}{l}1.84^{* *} \\
1.46\end{array}$ & $\begin{array}{l}0.150^{\text {w* }} \\
0.119\end{array}$ & $\begin{array}{l}26.0^{*} \\
41.1\end{array}$ & $\begin{array}{l}3.51^{* *} \\
2.18\end{array}$ & $\begin{array}{l}63.2^{* *} \\
76.6\end{array}$ & $\begin{array}{l}37.1^{* *} \\
30.3\end{array}$ & $\begin{array}{l}1.29 \\
1.35\end{array}$ & $\begin{array}{l}76 * * \\
81\end{array}$ & $\begin{array}{l}45 * * \\
52\end{array}$ & $\begin{array}{l}7^{* *} \\
9\end{array}$ & $\begin{array}{l}15^{* *} \\
19\end{array}$ & $\begin{array}{l}342^{* *} \\
225\end{array}$ & $\begin{array}{l}29 * * \\
46\end{array}$ \\
\hline $\begin{array}{l}\text { S.E. of the } \\
12 \text { native } \\
\text { samples }\end{array}$ & & 0.01 & 0.001 & 0.5 & 0.01 & 0.1 & 0.1 & 0.00 & 0.3 & 0.6 & 0.3 & 0.3 & 2 & 1 \\
\hline $\begin{array}{c}1925 \text { vs } 1927 \\
1950 \text { vs } \\
1925 / 1927\end{array}$ & & $*$ & $* *$ & $* *$ & $*$ & $* *$ & $* *$ & & $*$ & $*$ & $* *$ & $* *$ & $*$ & $* *$ \\
\hline
\end{tabular}

1 Humic acid/Fulvic acid ratio.

${ }^{2}$ Dehydrogenase activity was measured as nmol formazan released $/ \mathrm{g}$ dry soil/hour.

$*$,* Significantly different from adjacent revegtated range at $P \leq 0.05$ and $P \leq 0.01$, respectively, as determined by the $t$-test.

chelating resin. The humic acid/fulvic acid ratios further confirmed this change in composition of the OM. Dehydrogenase activity of the revegetated soil was lower in the 1925 than in the 1950 site.

Although the trend of the total water-stable aggregates did not correlate with the OM content of the soil, there was increased aggregation in the smaller-sized $(<1.0-\mathrm{mm})$ aggregate fraction during the early stages of revegetation. In the revegetated soil, bulk density, defined as the mass of dry soil per unit bulk volume, decreased from the 1950 to the 1925 site. Since there was no change in texture, the soil was thus more loose and porous in the 1925 site than in the 1950 site. This was also reflected in the change in the larger-sized $(>1.0-\mathrm{mm})$ water-stable aggregates.

More $\mathrm{N}$ was released into solution by the $6 \mathrm{~N}$ hydrochloric acid from the 1950 revegetated soil than from any of the other soils. Almost all hydrolysable $\mathbf{N}$ was accounted for by the sum of (amino acid + hexosamine + ammonium)- $\mathrm{N}$ in the 1950 revegetated soil but, with all other five soils, around $10 \%$ of the total hydrolysable $\mathrm{N}$ was not identified.

The roots of the 1950 revegetated field had the highest caloric content (Table 2). Still, the rootmass of the native range represented a higher potential source of a vailable energy than that of the abandoned fields returning to native range even after 55 years.

\section{Discussion}

The 3 pairs of native versus revegetated native ranges were not replicated by year because similarly treated, nearby abandoned fields were not available; historically, only a field was set aside. However, inasmuch as the data of the 3 native range sites generally demonstrated good agreement and the recovery data always sequentially approached the native range data (Table 3 ), it is reasonable to accept the data from the revegetated native ranges as representative of their position in the successional sequence.

More than 55 years are required for the revegetated, abandoned crop fields to approach native range conditions if they are moderately grazed after abandonment, even though the 1925 field was only cultivated for 15 years. On the revegetated sites the high proportion of blue grama indicates that this grass is more plentiful during succession than at climax. This study supports the conclusions of Whitman et al. (1943) that 60 years or more may be required for the development of climax vegetation by the process of natural revegetation in grazed fields.

Even though the below-ground root material was less in the revegetated areas, above-ground productivity was greater partly because of the chemical properties of the soils.

Rice and Pancholy (1972) found that inhibition of nitrification increased with the progress of succession toward the climax ecosystem. It thus appears likely that the greater inhibition of nitrification aids in the buildup of the available $\mathrm{N}$ in the form of ammonium-H $\left(\mathrm{NH}_{4}-\mathrm{N}\right)$. Rice (1976) showed that the amount of $\mathrm{NH}_{4}-\mathrm{N}$ increased from a low in the first successional stage to a high in the climax, whereas the amount of nitrate-N $\left(\mathrm{NO}_{3}-\mathrm{N}\right)$ decreased from a high in the first successional stage to a low value in the climax. The $\mathrm{NH}_{4}-\mathrm{N}$ values in the present study were 2.12 and 4.82 $\mu \mathrm{g} / \mathrm{g}$ (native range: $5.64 \mu \mathrm{g} / \mathrm{g}$ ), while the $\mathrm{NO}_{3}-\mathrm{N}$ values were 6.35 and $3.52 \mu \mathrm{g} / \mathrm{g}$ (native range: $3.17 \mu \mathrm{g} / \mathrm{g}$ ) for the 1950 and 1925 revegetated fields, respectively.

Dormaar and Ketcheson (1960) noted that corn roots in $\mathrm{NH}_{4}-\mathrm{N}$ treated soils exhibited greater ramification than those in $\mathrm{NO}_{3}-\mathrm{N}$ treated soils, while Bosemark (1954) established that at increased $\mathrm{NO}_{3}-\mathrm{N}$ levels an inhibition of root growth of wheat was the result, in part, of reduced cell multiplication. It may thus be postulated that both increased above-ground biomass, caused by the probable higher over the season $\mathrm{NO}_{3}-\mathrm{N}$ levels in the revegetated soils, (i.e., earlier in the successional stages), and increased rootmass, caused by higher over the season $\mathrm{NH}_{4}-\mathrm{N}$ levels, (i.e., at the climax ecosystem stage), are credible observations.

An alternative explanation for increased above-ground biomass on the revegetated fields would be the increased mineralization of $\mathbf{N}$ in the organic matter during the period of cultivation of the prairie range. Since a large percentage of the OM in Brown Chernozemic soils is still only partially decomposed (Dormaar 1975), there is a potential for considerable mineralization. Cycles of drying and wetting will further enhance this mineralization process. It is likely that both mechanisms, i.e., the effect of the $\mathrm{NO}_{3} / \mathrm{NH}_{4}$ ratios and increased mineralization due to the period of cultivation, contributed to the increased above-ground productivity. Schuman et al. (1984) showed that a significant loss in organic C and $\mathbf{N}$ occurred as a result of 5 years of cultivation when compared to native range sites.

On the basis of the decrease in OM extractable by chelating resin, increase in the humic acid/fulvic acid ratios, and increased aggregation further along the successional sequence, it may be 
postulated that, initially, mineral matter will be temporarily held together (Dormaar 1983) in small aggregates by organic substances of low molecular weights. As these organic molecules undergo polycondensation and possibly ramify with time, the size of aggregates will increase.

Increased rootmass will yield increased root exudates. Since monosaccharides, major constituents of root exudates, are active ingredients in stabilizing soil structure (Cheshire 1979), they will succeed the low molecular weight organic substances to become the dominant cementing agent. This will allow the water-stable aggregates to further increase in size. Finally, inasmuch as the percentages of water-stable aggregates of the native range and the 1925 revegetated soil were similar, it appears that the ratio distribution of the monosaccharides within the root exudates during the successional sequence has accelerated aggregation.

Pancholy and Rice (1973) conducted investigations on the revegetation of abandoned fields in central Oklahoma and southeastern Kansas and suggested that the monitoring of soil enzyme activity may indicate the plant growth potential of a soil and give insight into the microbial processes necessary for soil formation. They found that the dehydrogenase activity generally increased as revegetation of abandoned fields progressed. However, in the present study, dehydrogenase activity was less in the 1925 than in the 1950 field. The findings by Pancholy and Rice (1973) and this study are probably region-specific, i.e., Oklahoma vs Alberta, because of local climatic conditions. The average annual precipitation in the tallgrass prairie revegetation area studied by Pancholy and Rice (1973) was $810 \mathrm{~mm}$, while precipitation at the Manyberries Substation averages about $310 \mathrm{~mm}$ annually.

Because of less rootmass in the revegetated soils than in the native range, potential energy flow from this rootmass into the soil system was still not at par with that of the native range soil system. A similar observation was made for energy input under native range versus crested wheatgrass (Dormaar et al. 1978). To allow the soil to sooner regain its native range status following abandonment of cultivated land, revegetated range may have to be subjected to light or no grazing pressures to allow the vegetation to continue to increase its rootmass and increase the soil organic matter levels. The decision to allow the return of cultivated land in southeastern Alberta to its native range status (Fig. 1) under the existing semi-arid climatic conditions seems justified in terms of soil quality.

\section{Literature Cited}

Association of Official Agricultural Chemists. 1950. Official methods of analysis. 7th ed., Washington, D.C.

Booth, W.E. 1941. Revegetation of abandoned fields in Kansas and Oklahoma. Amer. J. Bot. 28:415-422.

Bosemark, N.O. 1954. The influence of nitrogen on root development. Physiol. Plant. 7:497-502.

Bremner, J.M. 1965. Organic forms of nitrogen. In: C.A. Black (ed), Methods of Soil Analysis. Part 2. Chemical and Microbiological Properties. Agron. 9:1238-1255. Amer. Soc. Agron. Madison, Wis.

Brink, R.H., Jr., P. Dubach, and D.L. Lynch. 1960. Measurement of carbohydrates in soil hydrolyzates with anthrone. Soil Sci. 89:157-166.

Cheshire, M.V. 1979. Nature and origin of carbohydrates in soils. Academic Press, New York.

Dormaar, J.F. 1973. Extraction of organic matter from Chernozemic Ah horizons. Sci. Soil 1973:71-79.
Dorman, J.F. 1975. Susceptibiity of organic matter of Chernozemic Ah horizons to biological decomposition. Can. J. Soil Sci. 55:473-480.

Dormaar, J.F. 1983. Chemical properties of soil and water-stable aggregates after sixty-seven years of cropping to spring wheat. Plant Soil 75:51-61.

Dormar, J.F., A. Johnston, and S. Smoliak. 1978. Long-term soil changes associated with seeded stands of crested wheatgrass in southeastern Alberta, Canada. Proc. 1st Intern. Rangeland Congr. (Denver, Colo.): 623-625.

Dormaar, J.F., A. Johnston, and S. Smoliak. 1980. Organic solventsoluble organic matter from soils underlying native range and crested wheatgrass in southeastern Alberta, Canada. J. Range Manage. 33:99-101.

Dormaar, J.F., and J.W. Ketcheson. 1960. The effect of nitrogen form and soil temperature on the growth and phosphorus uptake of corn plants grown in the greenhouse. Can. J. Soil Sci. 40:177-184.

Dormaar, J.F., and U.J. Pittman. 1980. Decomposition of organic residues as affected by various dryland spring wheat-fallow rotations. Can. J. Soil Sci. 60:97-106.

Federer, W.T. 1955. Experimental design. Macmillan Co., New York, N.Y.

Gieseker, L.F. 1931. Soils of Hill County. Soil reconnaissance of Montana. Preliminary report. Mont. Agr. Exp. Sta. Bull. 246.

Haug, P.T., and George M. Van Dyke. 1968. Secondary succession in abandoned cultivated fields: an annotated bibligraphy. Oak Ridge National Laboratory. Oak Ridge, Tenn.

Lauenroth, W.K., and W.C. Whitman. 1971. A rapid method for washing roots. J. Range Manage. 24:308-309.

Lodge, R.W., and J.B. Campbell. 1965. The point method and forage yield tables for determining carrying capacity. Mimeo. Publ., Agr. Can. Res. Stn. Swift Current, Sask.

Moss, E.H. 1959. Flora of Alberta. Univ. of Toronto Press, Toronto, Ont.

Pancholy, S.K., and E.L. Rice. 1973. Soil enzymes in relation to old field succession: amylose, cellulose, invertase, dehydrogenase, and urease. Soil Sci. Soc. Amer. Proc. 37:47-50.

Rice, E.L. 1976. Allelopathy and grassland improvement, p. 90-111. In: J.R. Estes and R.J. Tyre (eds), The Grasses and Grasslands of Oklahoma. Ann. Okla. Acad. Sci. No. 6, S. Roberts Noble Foundation, Ardmore, Oklahoma.

Rice, E.L., and S.K. Pancholy. 1972. Inhibition of nitrification by climax vegetation. Amer. J. Bot. 59:752-755.

Ridley, A.O., and R.A. Hedlin. 1968. Soil organic matter and crop yields as influenced by the frequency of summerfallowing. Can. J. Soil Sci. 48:315-322.

Ross, D.J. 1971. Some factors influencing the estimation of dehydrogenase activities of some soils under pasture. Soil Biol. Biochem. 3:97-110.

Schuman, G.E., R.A. Bowman, E.M. Taylor Jr., and L.E. Woods. 1984. Comparison of soil properties on cropland and rangeland catenas. Agron. Abstr. 1984 Annual Meeting of the Amer. Soc. Agron. Las Vegas, Nevada. November 25-30, 1984.

Tomanek, G.W., F.W. Albertson, and Andrew Riezel. 1955. Natural revegetation on a field abandoned for thirty-three years in central Kansas. Ecology 36:407-412.

U.S. Salinity Laboratory Staff. 1954. Diagnosis and improvement of saline and alkaline soils. Agr. Handb. No. 60, USDA. U.S. Government Printing Office, Washington, D.C.

Walkley A., and I.A. Black. 1934. An examination of the Degtjareff method for determining soil organic matter, and a proposed modification of the chromic acid titration method. Soil Sci. 37:29-38.

Whitman, Warren C., H. Theo. Hanson, and Gordon Loder. 1943. Natural revegetation of abandoned fields in western North Dakota. N.D. Agr. Exp. Sta. Bull. 321

Yoder, R.E. 1936. A direct method of aggregate analysis of soils and a study of the physical nature of erosion losses. J. Amer. Soc. Agron. 28:337-351. 